\title{
PARA ALÉM DAS FRONTEIRAS \\ NACIONAIS: TRANSNACIONALIZAÇÃO E INTERNACIONALIZAÇÃO RELIGIOSA, NOVAS FORMAS DE “SER” E “ESTAR” NA POLÍTICA
}

\author{
Mauro Meirelles ${ }^{1}$
}

\begin{abstract}
Resumo: O presente trabalho se propóe a realizar um estudo comparativo acerca do imaginário político e religioso que se faz presente em três capitais cisplatinas, a saber, Porto Alegre, Buenos Aires e Montevidéu. Para isto, centramos nossa análise nos fluxos de redes de lideranças religiosas pentecostais e afro-brasileiras que recobrem a bacia do Rio da Prata e no enquadramento que estes atores religiosos fazem acerca da relação entre religião e política. Especificamente, nos interessa pensar a religião e as formas pelas quais ela se transnacionaliza, produzindo um imaginário coletivo com diferentes representaçóes acerca do político e do religioso em função de diferentes marcos interpretativos do real.
\end{abstract}

Palavras-chave: Transnacionalização e internacionalização; Religião e Política; Pentecostalismo e Religióes afro-brasileiras.

\begin{abstract}
This paper propose a comparative study concerning religious and politics imageries in three cisplatine cities, namely, Porto Alegre, Buenos Aires e Montevidéu. In order to do this task, we focus in Pentecostal and Afro-Brazilian religious leaders that establish networks recovering the Basin of Rio da Prata, and in the mainframe in which these religious agents establish the relations between religion and politics. Specifically, we are interested to think how religious transnationalization produces a collective imagery evolving different representations concerning politics and religion in function of different interpretive points of view.
\end{abstract}

Keywords: Transnacionalization and internacionalization; Religion and Politics; Pentecostalism and Afro-brazilian's religion.

\section{INTRODUÇÃO}

Pensar a forma como as pessoas vêem o mundo, se colocam nele e com ele interagem das mais diversas maneiras não é um empreendimento de fácil

${ }^{1}$ Doutorando em Antropologia Social (PPGAS/UFRGS), Bolsista Capes e Pesquisador ligado ao Núcleo de Estudos da Religião (NER/UFRGS).

Debates do NER, Porto Alegre, Ano io, N. I6, P. I6I-I8I, JUl./Dez. 2009 
conclusão mesmo para o mais atento e perspicaz dos antropólogos. Nesta direção, e consciente do empreendimento ao qual nos propomos, buscamos no presente trabalho realizar alguns apontamentos acerca das relaçóes que se tecem entre imaginários religiosos e políticos em três capitais sul-americanas, a saber: Porto Alegre, Buenos Aires e Montevidéu. Para isto, centramos nossa análise nos fluxos que recobrem duas redes transnacionais, uma ligada as religióes de matriz africana e afro-brasileira e, outra, que envolve diversos grupos evangélicos de matriz pentecostal e neopentecostal que interagem neste espaço geográfico-cultural.

Em especial, dado o trabalho de mapeamento que estamos realizando - através de projeto de pesquisa financiado pelo $\mathrm{CNPq}^{2}$ - temos que alguns desses fluxos já nos são conhecidos e apontam em direçóes diversas.

No caso daqueles ligados as religiōes de matriz africana e afro-brasileira têm-se que tais fluxos parecem ser, em grande parte, unidirecionais. E, deste modo, destaca-se entre estes, o fato de que tanto o Uruguai como a Argentina mostram-se, na atualidade, como detentores de uma posição de meros receptores de mães e pais-de-santo provindos já desde meados dos anos 1980 do Brasil e, mais recentemente, a partir dos primeiros anos deste novo século, da Nigéria.

Já no que se refere aos evangélicos tanto de matriz pentecostal como neopentecostal temos que tais redes se mostram muito mais intrincadas e apontando para diversas partes do mundo, não só no que tange a grandes denominaçóes já institucionalizadas e tidas como sendo notadamente brasileiras como é o caso da Igreja Deus é Amor (DA), da Igreja Universal do Reino de Deus (IURD) e da Igreja Internacional da Graça de Deus (IIGD), como também, de outras que possuem um modelo organizacional de base congregacional ou de célula e que, diferentemente das primeiras, possuem uma membresia de no máximo 20.000 fiéis. É o caso por exemplo, do ministério Cruzadas de Fé (CF), pastoreada por Isaías Figueiró no Brasil e, na Argentina, da Igreja Rey de Reyes (IRR). Contudo, modelos organizacionais híbridos se fazem presentes, como é o caso da Igreja Batista Renovada (BRASA) que, apesar de basear-se em modelo congregacional adentra ao

\footnotetext{
${ }^{2}$ A realização desta pesquisa contou com apoio do CNPq através de recursos provenientes do Projeto de Pesquisa "Transnacionalização afro-religiosa e pentecostal no MERCOSUL", donde provêm parte dos dados que aqui apresentamos.
}

Debates do NER, Porto Alegre, ano io, N. I6, P. I6I-I8I, JUl./Dez. 2009 
campo político a partir da interação com redes da qual, a priori, não faziam parte em função de sua constituição histórica diferenciada ${ }^{3}$.

Todavia, no caso dessas igrejas de matriz pentecostal e neopentecostal a situação parece ser um pouco diversa daquela observada entre aqueles religiosos pertencentes as religióes de matriz africana e afro-brasileira uma vez que, os fluxos entre pessoas e países irá, em grande parte, depender das redes pessoais existentes entre pastores e ministérios diversos, assim como, da forma como essas redes transnacionais estão estruturadas em termos de financiamentos, acordos e interesses evangelísticos de cada um daqueles que nestas redes interagem.

Neste sentido, pensar a religião no contexto transnacional envolve entender essa dinâmica e a forma como esta se assenta no interior do imaginário coletivo e produz, neste, diferentes representaçóes acerca do político e do religioso, em especial, no que tange a forma como estes se colocam tanto no campo político como no religioso em função de diferentes marcos interpretativos do real e do conhecimento das "regras do jogo" (Bourdieu, 2007). Outrossim, no intuito de dar conta do "dito" e do "não-dito" no que se refere a especificidade dessas redes têm-se que entrevistas realizadas com pastores, pais-de-santo e políticos, entre os anos de 2007 e 2009, apontam para a existência de diferentes estratégias de expansão destas religiōes, tanto aquelas de matriz africana e afro-brasileira como aquelas de matriz pentecostal e neopentecostal.

Especial destaque deve ser dado, neste caso, a três fatores que parecem ser determinantes na forma como estas redes estão estruturadas em função dos diferentes agentes que compõem e interagem nestas redes. São eles: 1) as redes de instituições, pessoas, interesses, instituições e financiamentos das quais fazem parte cada um dos atores envolvidos; 2 ) a posição que cada agente ocupa nesta rede; e, 3) os interesses que estes agentes possuem em firmar bases sólidas para fora de seu território nacional. Destaca-se ainda que, para além destas questôes até aqui colocadas, dados recentes de pesquisa etnográfica e

\footnotetext{
${ }^{3}$ Neste sentido, importa lembrar que, muito mais do que uma religião autóctone ou "made in brazil", os batistas, antes de mais nada, derivam de um modelo expansionista inglês e norte-americano ligado ao trabalho de missão e a salvação de almas no novo mundo e que por isso, possuem, marcos histórico-interpretativos um pouco diferenciados de outras igrejas de matriz, também, evangélico-pentecostal.
}

Debates do NER, Porto Alegre, Ano io, N. I6, P. I6I-I8I, JUl./Dez. 2009 
de questionários apontam para a existência de uma matriz cultural comum, fato que, parece facilitar a conjunção de subsunçores específicos em torno de um imaginário comum e de um ethos social peculiar existente naquilo que Ángel Rama (2001) denomina de área cultural cisplatina.

\section{RELIGIĀO E POLÍTICA NO CONTEXTO TRANSNACIONAL: DIFERENTES FORMAS DE SER E ESTAR NA POLÍTICA}

Depois de quase três meses em campo, de flanar no interior de redes de religiosos ligados a religióes de matriz africana e afro-brasileira e/ou outras compostas por pastores e políticos ligados a diferentes denominaçóes pentecostais e neopentecostais tanto em Montevidéu (UY) como em Buenos Aires (AR), me é possível tecer algumas consideraçōes acerca da forma como estas redes de pastores e/ou pais e mães-de-santo estão estruturadas em termos locais, nacionais e transnacionais. Em especial, enfoco em sua reconstituição a forma como essas redes se estruturam em funçáo de centros de poder e prestígio que se encontram fora da territorialidade geográfico-espacial de seu país, ora apontando para algumas cidades brasileiras ${ }^{4}$, ora para outros países e cidades do continente sul-americano e do mundo 5 .

${ }^{4}$ Como é o caso, por exemplo: da Igreja Batista Renovada argentina da qual faz parte Anabella Schiaffino que aponta para um contato que teve com o missionário R. R. Soares da Igreja Internacional da Graça de Deus com sede mundial na cidade do São Paulo; da Igreja Batista Renovada do uruguaia que possui relaçôes pessoais e profissionais fortíssimas com o pastor Luiz Bazerque de Igreja Batista Renovada de Porto Alegre, servindo inclusive como parceira desta na realização de atividades de missão desta, a qual possui um curso para aqueles que realizam trabalho de missão no exterior e realizam nesta e em outras igrejas batistas localizadas em diferentes províncias, uma espécie de estágio de cerca de 20 dias, onde são colocados em prática os conhecimentos de apreendidos em cerca de um ano e meio de curso realizado na sede da referida igreja em Porto Alegre.

${ }^{5}$ Como é o caso, por exemplo: da Igreja Rey de Reyes que, segundo Joaquín Algranti em texto publicado neste número da revista Debates do NER, contou com a presença de Cláudio Freidzon em Dallas e New Jersey (Estados Unidos), em Málaga (Espanha), em Paris (França), e que em novembro se prepara para ir a Curitiba/PR (Brasil) para um evento promovido por uma igreja local que conta com uma membresia de cerca de 20 mil fiéis; ou ainda, no caso sul-americano, da sede nacional da Igreja Deus é Amor do Uruguai que, em maio de 2009, preparava um de seus pastores para o trabalho de missão na Cidade do México; entre outros.

Debates do NER, Porto Alegre, ANo io, N. I6, P. I6I-I8I, JUl./Dez. 2009 
No caso dos afro-brasileiros temos que tal fluxo religioso tem como centro geográfico os terreiros e casas de religião, principalmente de Batuque e Quimbanda, existentes em Porto Alegre, onde, é comum, dentro de sua mitologia imagético-fundacional a referência a preceptores e religiosos provindos, em sua maioria desta cidade. Neste sentido, mesmo depois de 10 anos da publicação de Axé MERCOSUL, escrito por Ari Pedro Oro, pouca coisa mudou e, nas noites de ritual em terreiros e casas de religião de Buenos Aires, não é muito difícil, em determinadas festas e obrigações destas casas, encontrarmo-nos com Mãe Yeda de Ogum de Porto Alegre, ou ainda, no caso do Montevidéu, a referência a época a que pai Ailton de Oxalá andava por essas bandas do Rio da Prata.

Contudo, diferentemente do que parece, temos que a presença de pais e mães-de-santo brasileiros nas duas margens do Rio da Prata se dá muito mais no plano fundacional do que, propriamente, no âmbito de sua presença física. Isso se dá, sobretudo, por duas razóes. A primeira reside no fato de haver hoje, tanto na cena uruguaia como argentina, um grande número de pais e mãesde-santo prontos, os quais, possuem um grande número de filhos-de-santo fato que, enseja muito menos a presença física dos preceptores brasileiros. A segunda que, diferentemente da geração anterior, esses novos pais e mãesde-santo estáo muitos mais inseridos em uma rede local buenarense, ou montevideana, onde, se iniciaram na religião, e não, à uma rede de preceptores religiosos localizados fora das fronteiras nacionais de seus países.

Todavia, também, não é tão incomum que encontremos na casa de Mãe Yeda de Ogum, de Pai Cléon de Oxalá e Jorge Verardi de Xangô, em Porto Alegre, filhos-de-santo argentinos que estão lá para aprontarem-se na religião. Algo também constatado por Bem (2007) em relação ao caso uruguaio, onde, na casa de Mãe Chola, em Santana do Livramento, era comum a presença tanto de pais e mães-de-santo uruguaios como brasileiros.

A isto, deve-se agregar o fato de que, apesar de Mãe Chola estar do lado brasileiro da fronteira, esta, possui relativa presença na cena montevideana, onde, mantêm uma casa de religião freqüentada por pais e mães-de-santo da capital uruguaia por ela iniciados na religião e/ou que estão sobre sua orientação religiosa com vistas a se tornarem, também, ialorixás e babalorixás, como seus preceptores religiosos.

Debates do NER, Porto Alegre, ANo io, N. I6, P. I6I-I8I, JUl./DeZ. 2009 
Já no plano político, as redes constituídas entre os afro-religiosos se mostra, em grande parte, sobreposta a religiosa, uma vez que, esta, se relaciona, sobretudo, a garantia de direitos constitucionais ligados a liberdade de culto, a formação de entidades representativas diversas e a lutas históricas do movimento negro. Isso, pelo menos no caso brasileiro. Todavia, ao olhar atento do antropólogo que por estas redes se desloca, não escapa o fato de que essas bandeiras de luta estão muito mais ligadas a uma disputa entre lideranças, que buscam ocupar um lugar de prestígio no meio do qual fazem parte, do que a uma luta por direitos históricos.

Em torno de associaçóes e movimentos políticos pontuais, acaba por emergir desse modo, uma rede de relações entre pessoas que não difere em muito daquela que observa-se no plano religioso, a qual, está, na maioria das vezes, ligada a certa descendência-de-santo e/ou vínculos fraternais entre pessoas que dela participam (Meirelles, 2008).

Neste sentido, apesar de dispersa, essa rede possui ramificaçôes e lutas que se estendem para além das fronteiras nacionais, as quais, no caso argentino, se constroem no entorno de lutas pontuais ligadas ao reconhecimento de suas práticas religiosas e a busca de uma maior liberdade no que tange a forte ingerência do catolicismo no interior do Estado através da Secretaria de Cultos.

Já no Uruguai, o que se observa é algo um pouco diverso, e pelas bandas orientais do Rio da Prata, o que vemos é a formação de uma rede política em torno da Mãe Susana de Oxum que, através da Lista 7777, busca levar para o campo político uma série de questóes relacionadas a essa prática religiosa específica e a combater a aporia que se produz entre as religióes afro-brasileiras e evangélicas, desde a entrada da Igreja Universal do Reino de Deus neste país.

Já, entre os evangélicos de matriz pentecostal e neopentecostal, a situação é um pouco diversa daquela observada entre aqueles ligados ao segmento afro-brasileiro nestes países e, emergem deste segmento específico pelo menos três redes que não possuem nós em comum, mas que, estão assentadas sobre fortes estruturas organizacionais, sobre objetivos religiosos específicos e, ou ainda, sobre projetos políticos locais destes grupos.

Debates do NER, Porto Alegre, ano io, N. I6, P. I6I-I8I, JUl./Dez. 2009 
No que tange aquelas baseadas sobre forte estrutura organizacional temos a Igreja Universal do Reino de Deus que, de forma mimética e adaptada ao contexto local de Buenos Aires e Montevidéu, se utiliza do discurso do outro e de elementos da realidade local para construir seu próprio campo de contingência e incidência no plano mítico-ritual daqueles que freqüentam seus templos nestas cidades (Meirelles, 2005). Neste sentido, em conversa informal travada com um dos pastores da referida igreja acabei por descobrir que entre os cerca de 10 pastores que estavam encarregados do trabalho religioso no templo maior de Montevidéu, situado na 18 de julho, 6 eram brasileiros e que, não havia nenhuma preparação anterior para sua vinda para cá. Outrossim, além do convite para ir ao culto que se realizaria no domingo, $1^{\circ}$ de maio, este, também, me disse que havia uma certa diretriz a ser seguida no que se refere as chamadas campanhas, as quais, eram definidas pelo bispo e sua equipe.

Dias depois, retornei ao referido templo, uma vez que, como havia me dito meu informante, no domingo, dia $1^{\circ}$ de maio, haveria um culto que estava sendo preparado há algum tempo a partir do Salmo 91, onde, neste dia, se fariam presentes 91 pastores que por 91 minutos estariam a celebrar o culto e a sacralizar 91 quilos de sal que seriam utilizados durante o referido culto. Não muito diferente ao que se observa no Brasil, ao adentrar no templo, situado na Avenida 18 de julho, por volta das 13 horas da tarde, dei-me logo com o interior de um antigo cinema ou teatro, o qual dispunha de cerca de 900 a 1000 lugares para o público e que, naquele momento encontravam-se ocupados e com pessoas em pé, atrás da última fileira, onde me coloquei para observar a cena.

Contudo, as semelhanças param por aí e, ao olhar para o palco a imagem que tinha a minha frente lembrava aos portugueses que em terras brasileiras aportaram e, em Pindorama, celebraram a primeira missa. A diferença é que, em Montevidéu não traziam bandeiras com a cruz de malta, mas usavam um hábito branco com a referida cruz em vermelho - uma clara alusão as cruzadas. Ao fundo cobrindo a parede um gigantesco banner de 6 metros de altura e cerca de 3 metros de largura, onde, em letras garrafais podia-se ler todo o Salmo 91.

Debates do NER, Porto Alegre, ANo io, N. I6, P. I6I-I8I, JUl./DeZ. 2009 
No desenrolar do culto o clássico modelo iurdiano evocativo dos males do mundo, típico desta igreja, onde o pastor evocava aos ali presentes se tinham algum problema, se eram vítimas de bruxaria, mal-olhado, etc., enquanto que, paralelamente, os auxiliares abriam uma lona em frente ao palco e ali despejam os noventa e um quilos de sal. Estando a cena pronta e quando, cerca de um quarto dos ali presentes se mostravam vítimas de algum mal, iniciou-se a leitura do Salmo, onde, o termo "pestilento", referendado várias vezes no Salmo, era intercambiado a toda hora por males que os fiéis acusavam possuir, adquirindo, assim, materialidade no imaginário daqueles que ali se faziam presentes.

Identificado e materializado o mal, em seguida eram evocados a passar pelo caminho de sal, momento em que, "o pestilento", agora passava a ter uma "persona" e "um nome", qual seja: pomba-gira, exu, etc. Isso posto, era o momento de iniciar a "peleia com os exus" que, ao se manifestarem ao passarem pelo caminho de sal eram imobilizados e arrastados para cima do palco pelos auxiliares que os continham colocando o braço sobre o pescoço e subjugando-os, de modo que, este, o fiel, ficava submisso a pressão e a força do braço do pastor que, em uma clara chave de braço, semelhante aquela que vemos nos ringues de luta livre, conduzia este, praticamente sem nenhuma resistência, até o palco. No palco, pouco depois, era o momento do espetáculo e as velhas cenas que nas madrugadas da televisão já são clichês ali se faziam presentes.

Em suma, podemos dizer que todos os que ali estavam eram, na medida do possível instigados a fazerem parte dessa luta e, ao evocar a autoridade do Espírito Santo para expulsar os demônios que ali se faziam presentes, o pastor evocava, também, a autoridade do Bispo Edir Macedo e a sua, apresentando ao público a santíssima trindade iurdiana, algo que, em cultos realizados no Brasil, eu, ainda não havia visto. Com isto na cabeça, na entrada deste mesmo templo da IURD, dias depois, voltei a conversar com meu informante e lhe comentei acerca do fato que, aqui em Montevidéu, o culto me pareceu bem mais "pegado", para usar aqui a expressão nativa, que no Brasil. Em resposta, ele me disse que por aqui, em Montevidéu, [...] Tinha que ser assim, é preciso aquecer o público. Porquê? Porque os uruguaios, eram muito frios e incrédulos em termos de religiāo.

Debates do NER, Porto Alegre, ano io, N. I6, P. I6I-I8I, JUl./Dez. 2009 
Neste sentido, aproveitando a "deixa" que me havia dado de realizar essa comparação entre Brasil e Uruguai, lhe questionei como era a participação da IURD na política por aqui, visto que, no Brasil, era normal que pastores de sua Igreja se candidatassem a cargos públicos e, de pronto, esse me disse que em Montevidéu, eles já haviam andado por essa seara. Mas que, devido ao envolvimento de alguns de seus membros com episódios de corrupção, foram obrigados a emitir uma nota pública informando a expulsão destes membros de sua Igreja. Contudo, segundo ele, havia, também, planos de retornarem a cena política e, dada as peculiaridades do sistema eleitoral uruguaio, quem sabe, lançarem um candidato a Presidência.

No pólo oposto aquele que se situa os evangélicos da IURD, estão, aqueles ligados a outra igreja evangélica brasileira, a Deus é Amor. E, tornase aqui, interessante relatar a forma como consegui acesso a Nerísio Costa, coordenador nacional da Deus é Amor no Uruguai, uma vez que, meses antes, dois colegas de pesquisa haviam estado por lá e intentaram uma entrevista que, não se sucedeu, com alguém ligado a referida Igreja. Mas que, no meu caso, tal encontro com este se deu de forma bastante casual, uma vez que, estava hospedado num hotel próximo a sede central da mesma e, no dia em que retornava ao Brasil e estava a aguardar o taxi que me levaria ao aeroporto, este, chegou na portaria e perguntou ao recepcionista quem é que pagaria a sua estadia, ele ou a igreja pois, tinha há pouco chegado de Lima, no Peru, onde estava em trabalho de missão fazia dois anos e, agora, retornava ao Uruguai de onde havia partido para, assumir a Coordenação Nacional da referida igreja no Uruguai.

Neste sentido, aproveitei o momento para me apresentar, falando um pouco do trabalho que estava a desenvolver e se este poderia me conceder uma entrevista na medida em que, me interessava saber a forma como sua igreja, a Deus é Amor, se colocava tanto no âmbito político como religioso, uma vez que, já sabia de trabalhos anteriores que, pelo menos no caso brasileiro, estes, eram avessos a inserção de religiosos no campo político. $\mathrm{E}$, diferentemente do esperado, esse me disse que não haveria problema e que, assim que retornasse ao Uruguai o procurasse para conversarmos um pouco sobre isso - e foi o que fiz.

Debates do NER, Porto Alegre, Ano io, N. I6, P. I6I-I8I, JUl./Dez. 2009 
$\mathrm{Na}$ entrevista que se sucedeu cerca de uma semana depois quando retornei ao Uruguai, na própria sede da Igreja, fui informado por este que haviam adquirido um nova sede e que em breve estariam a se mudar para lá, onde, antes era um antigo cinema. No hall de entrada, alguns cartazes de missionários da Igreja que haviam estado por ali, no interior do templo, um jovem predicando a uns poucos fiéis e iniciando o louvor.

Enquanto subia com Nerísio para sua sala, este, me informou que o rapaz estava sendo treinado no pastorado e que, em breve, estaria indo para outro lugar predicar e, de fato, durante a entrevista fui informado que, este rapaz, estava sendo preparado para ir para a Cidade do México, para ajudar no trabalho que a igreja estava desenvolvendo por lá. Neste sentido, também me relatou ainda que, ele, havia sido designado para Montevidéu, com vistas a retomar o trabalho evangelístico que, aos olhos da matriz brasileira parecia estar estagnado por ali. Outrossim, no andar da entrevista me falou de sua trajetória, de sua entrada na Deus é Amor e de como havia chegado pela primeira vez ao Uruguai.

A isto, se sucedeu um breve relato do trabalho que havia desenvolvido em outros países e as dificuldades que a barreira lingüística impunha aos pastores, como no seu caso que, em 1999, quando chegou em Montevidéu, pela primeira vez, como pastor, não sabia nada de espanhol e teve que aprender por si, no dia-a-dia. Todavia, como bem coloca ele, hoje em dia a coisa é diferente e, de fato, os pastores vindos do Brasil, recebem uma preparação especial através do que ele chamou de escola bíblica e da realização de cursos de idioma na matriz brasileira ${ }^{6}$.

Já no que se refere se refere a posição da referida Igreja no que se refere ao campo religioso temos que, tanto no caso do Uruguai como no caso da Argentina, o destaque foi dado ao trabalho de evangelização realizado e a sua missão de levar a palavra de Deus a todos aqueles que se dispunham a com

${ }^{6}$ Nesta direção, devo lembrar que, em entrevista realizada com um pastor que me foi designado pelo senhor Jorge Camâra, responsável por este trabalho de missão na Argentina, este relatou-me que, no caso de pastores provindos de outros países, não havia tal treinamento para esse trabalho e que estes chegavam aqui "na cara e na coragem" como no seu caso, quando, foi designado pela direção da Igreja para predicar no Paraguai.

Debates do NER, Porto Alegre, ano io, N. I6, P. I6I-I8I, JUl./Dez. 2009 
ela ter contato. No caso do Uruguai, o destaque dado residiu, sobretudo, no trabalho de orientação aos valores cristãos e ao trabalho social desenvolvido pela Igreja em diversas instâncias. Este segundo, pouco destacado no caso da entrevista realizada com o pastor argentino, este, um paraguaio que há vinte anos reside em Buenos Aires, o qual enfatizou que, o trabalho da igreja por ali residia, sobretudo, em evangelizar e conquistar almas para o seu ministério.

No plano político, conforme me relatou meu informante uruguaio, a posição da Igreja é manter-se fora da cena política, uma vez que, isso é algo estatutário que regula a forma como a Deus é Amor se insere e percebe o político. Contudo, deixa transparecer em sua fala o fato de que, não vê com maus olhos essa participação evangélica na cena pública, mas que, apesar de serem procurados por representantes de diferentes listas partidárias, não se envolvem com o político. Segundo ele:

O máximo que fazemos aqui no caso do Uruguai, é orientar nossos féis a analisarem as diferentes propostas apresentadas pelos diferentes candidatos $e$ buscarem, dentre estes, homens de caráter e que defendam a palavra de Deus el ou valores cristãos, seja este, evangélico ou não.

Já no caso da Argentina, apesar de sustentada a mesma posição, de política não se fala no templo, nem no que tange a essa orientação mínima. Todavia, encerrada a entrevista, o próprio pastor me disse que, se queria saber sobre política devia procurar outras igrejas e ministérios, sobretudo, as igrejas dos pastores Héctor Gimenez, de Claudio Freidzon e o ministério de Carlos Annacondia.

No que se refere a Igreja do casal Freidzon temos que a Rey de Reyes, apesar de não participar de forma implícita da cena política como pudemos observar em relação a outras denominações, esta, durante o evento que acompanhamos demonstrou ter consciência de seu peso na cena religiosa argentina e estar articulada também no plano do "mundano", através de suas parcerias com os Conselhos de Pastores de diversas cidades e de suas iniciativas de ação social (Operação Vida) e de formação de lideranças

Debates do NER, Porto Alegre, ANo io, N. I6, P. I6I-I8I, JUl./DeZ. 2009 
(Breakthrough $\left.{ }^{7}\right)$. Nesse sentido, muito mais do que um presença incisiva com vista a defesa de interesses específicos, a Rey de Reyes, busca ocupar um lugar estratégico na medida em que, apesar de não colocar-se na berlinda e expor-se em disputas de poder, detém posições e projetos sociais que transcendem o ethos denominacional e operam sobre uma lógica diversa, de ocupação estratégica de um espaço secularizado que precisa ser reencantado (Weber, 2002 Pierucci, 1998).

E, por fim, temos uma terceira posição, a qual se coloca entre aquela assumida pelos evangélicos da IURD e aqueles ligados a Deus é Amor, esta, ligada aos batistas renovados que colocam, lado a lado, o político e o religioso. Neste sentido, o que se observa tanto no caso brasileiro como argentino é que há, entre os batistas, uma tendência maior a aproximar-se essas duas esferas em função da defesa e/ou envolvimento deste segmento em questóes pontuais como aquelas relacionadas a direitos constitucionais, sociais e/ou políticos. Todavia, apesar de, no caso argentino Anabella Schiaffino se apresentar como uma candidata do "segmento evangélico", esta, não contou com o apoio de nenhuma federação e/ou entidade representativa da totalidade desse segmento. Isto, algo um pouco diverso do que pudemos constatar no Uruguai, onde, porquanto, os batistas apenas estão a compor algumas listas de partidos, conforme nos relatou Omir Alves, pastor uruguaio, que por acaso, no dia em que realizamos a entrevista tinha acabado de receber em sua igreja um edil do departamento de Canelones.

Neste sentido, fica evidente uma postura diferenciada deste segmento evangélico pentecostal no que tange aos dois outros, uma que se alija (Deus é Amor) e outra que porquanto se coloca fora da cena política (IURD), pelo menos, no caso do Uruguai. Outrossim, em terras portenhas a situação não é

\footnotetext{
${ }^{7}$ Breakthrough é um evento destinado a lideranças religiosas que ocorre na sede da Igreja Rey de Reyes em Buenos Aires e que, além de contar com a presença de Carlos Annacondia. Neste sentido, na edição de 2009, da qual participamos, o evento contou com a participação de líderes religiosos provenientes de mais de 20 países. A saber: África do Sul, Argentina, Armênia, Bolívia, Brasil, Canadá, Chile, China, Colômbia, Equador, Estados Unidos, El Salvador, Espanha, Guatemala, Inglaterra, México, Nova Zelândia, Paraguai, Peru, República Dominicana, Suíça, Reino Unido, Uruguai e Venezuela.
}

Debates do NER, Porto Alegre, ano io, N. I6, P. I6I-I8I, JUl./Dez. 2009 
muito diversa daquela que encontramos no banda oriental de modo que, pelas bandas ocidentais do Rio da Prata, esses, também, estão organizados em uma lista de partido, a Lista 179 e possuem pelo menos uma candidata concorrendo pela segunda vez a deputada nacional ${ }^{8}$. Seu nome: Anabella Schiaffino.

No âmbito religioso, temos que tanto a rede em que Anabella se insere como quanto a que Omir Alves faz parte, apontam para o Brasil e o contato que tiveram com pastores brasileiros. É o caso, por exemplo, de Anabella que, em entrevista realizada, nos relatou seu contato por aqui com o missionário R.R. Soares da Igreja Internacional da Graça de Deus, ou ainda, de Omir Alves que, também, nos falou bastante do contato que possuía com pastores gaúchos, em especial, com Luiz Bazerque da Igreja Batista Renovada (BRASA) de Porto Alegre.

Mas, ainda fica a questão: o que leva essas diferentes denominações a se portarem de forma tão diversa em três países limítrofes e que, segundo defende Ángel Rama, estão sobre uma mesma área cultural de influência? É isso que, no item seguinte, tentaremos responder.

\section{PARA ALÉM DAS FRONTEIRAS NACIONAIS: NOVOS MUNDOS, VELHOS PARADIGMAS}

Como vimos, diversas são as posturas que tanto evangélicos como quanto afro-brasileiros adotam em relação ao campo político tanto no âmbito de seu pais de origem, no caso o Brasil, como quanto, fora dele. Outrossim, também nos foi possível constatar que, no âmbito transnacional prevalece, na maioria dos casos, as diretrizes dadas pela matriz brasileira, isso no caso da Deus é Amor e da Igreja Universal, as quais se caracterizam por uma forte estrutura hierárquica que deixa pouco espaço para que pastores a ela ligados, adotem posturas diferenciadas.

\footnotetext{
${ }^{8}$ A qual, conta com o apoio de pelo menos cinco religiosos, também candidatos e ligados a diferentes denominaçóes religiosas, como informa seu site de campanha, a saber: o Evangelista Rolando Di Grazia; o Pastor Alberto Savazzini; o Pastor Javier Lovecchio; o Pastor Eliseo Vasquez; e a Ministra Débora Gomesky.
}

Debates do NER, Porto Alegre, Ano io, N. I6, P. I6I-I8I, JUl./Dez. 2009 
Neste sentido, também se mostra como recorrente o fato de que, tanto no Uruguai como na Argentina, há um bom trânsito de pastores brasileiros que acabam por reproduzir em terras estrangeiras, as mesmas práticas que se fazem presentes em território brasileiro. No âmbito religioso, adaptado a especificidade local e incorporando elementos da cultura local são reinventados e trabalhados de forma diferenciada, onde, momentos de louvor são mais trabalhados no que nossos vizinhos hispano-hablantes denominam de "alabanza" e "peleias com exús", as quais, são com mais intensidade retratadas pelos pastores e, consequentemente, vividas com mais intensamente pelos fiéis. No âmbito político, o mesmo se observa, contudo, o espaço para o trabalho do pastor é bem menor e depende da diretriz dada por sua matriz denominacional, a exceção, dos batistas renovados.

No caso destes últimos, os batistas renovados, o que prevalece é a vontade do grupo que na igreja congrega, uma vez que, estes, diferentemente da Igreja Universal e da Deus é Amor, possuem um modelo organizacional congregacional que se caracteriza por comunidades religiosas de menor escala e mais ligadas a localidade donde se situam. É o caso por exemplo da BRASA em Porto Alegre que organiza eventos onde participam pastores ligadas a outras ramificações batistas renovadas, ou da congregação de Omir Alves e Anabella Schiaffino, que no momento da entrevista com eles realizada relataram a ida e/ou vinda de pastores ligados a sua congregação a terras brasileiras e/ou delas oriundos.

Já no caso casal Freidzon, as coisas parecem ser um pouco diferentes e mistura-se no interior do campo evangélico uma disputa de prestígio e poder simbólico - vendeta esta, característica dos afro-brasileiros - por meio da ocupação direta e/ou indireta de espaços cada vez maiores na cena pública ${ }^{9}$, ou ainda, a sua interlocução/participação em outras instâncias da vida política e social através dos Conselhos de Pastores da Cidades (CPC) onde possuem sede.

Sobremaneira, temos ainda que, estes, a revelia do que colocam os

${ }^{9}$ Através do desenvolvimento de ações sociais (Operação Vida), da entrega de prêmios a pessoas que se destacaram em suas áreas de atuação (Prêmio Shining), etc.

Debates do NER, Porto Alegre, ANo io, N. I6, P. I6I-I8I, JUl./Dez. 2009 
evangélicos ligados a Deus é Amor, deixam claro que, pelo menos no caso uruguaio, um dos elementos que facilita esse trânsito é, de certa forma, a proximidade lingüística, em especial, quando nos referimos a vinda de pastores do Rio Grande do Sul para o Uruguai. Tal constatação, nos enseja a arriscar que, pelo menos no caso dos batistas renovados, o que está em jogo, é um conjunto de representaçóes que são comuns as diversas etnias que compóem o seu público cativo, este, fundamentalmente ligado desde sua origem a chegada de imigrantes provindos de diversas partes da Europa ao sul do Brasil, a Argentina e ao Uruguai entre os fins do século XIX e início do XX.

Outrossim, no que se refere especificamente aos afro-brasileiros temos que o calcanhar de Áquiles é outro e que suas lutas e bandeiras políticas estão muito mais relacionadas a história de constituição de cada um dos estados nacionais supracitados do que a existência de uma hierarquia comum. Neste sentido, a esteira do que se observa no Brasil, é recorrente, tanto no caso da Argentina como no Uruguai, a existência de uma pluralidade de associaçóes e bandeiras ligadas a redes religiosas e de prestígio específicas de cada um destes países, sobretudo, no que se refere as lutas políticas por eles vivenciadas.

E deste modo, a guisa de uma breve conclusão podemos afirmar, com certo grau de certeza, que há no âmbito dos países e das religiōes estudadas certas recorrências que são observadas no interior de cada uma delas. Umas que apontam para questôes históricas relacionadas a própria forma como estas aportaram nos diferentes países, outras, que deixam evidente a existência de estruturas hierárquicas fortemente organizadas. Todavia, variaçóes podem ser observadas, em especial, no que se refere a liturgia e a forma como o culto é conduzido em cada uma das cidades supracitadas. Outrossim, dado o exposto até aqui, também nos foi possível, a partir da etnografia e de entrevistas realizadas constatar a existência de determinadas redes de interação que, aliadas a padróes de comportamento estruturados a partir de estruturas organizacionais fortemente hierarquizadas, acabam por reproduzir em terras cisplatinas formas de ser e estar no político que são típicas daquelas a que à estas igrejas estão ligados em território brasileiro.

Debates do NER, Porto Alegre, ANo io, N. I6, P. I6I-I8I, JUl./Dez. 2009 


\section{CONSIDERAÇŌES FINAIS: PENSANDO UMA TIPOLOGIA PARA O CASO CISPLATINO}

A partir do exposto e no intuito de tentar sistematizar algumas das constataçôes feitas no que tange aos três países estudados aponto, a guisa de uma breve conclusão, algumas consideraçóes gerais no que tange ao objeto que nos ocupamos no presente texto, qual seja, da forma como diferentes grupos religiosos se colocam na cena pública e na política em função de diferentes marcos interpretativos do real.

Em primeiro lugar, que há no mínimo três posições que são assumidas nos três países em relação a forma como o político e o religioso são por esses segmentos percebidos e por eles trabalhados: a) uma que os coloca fora das coisas do mundo e, conseqüentemente, da política; b) outra, que os coloca como agentes pró-ativos que entram na política em função de interesses específicos de sua instituição e/ou segmento; e, c) uma terceira, situada num ponto médio entre a primeira e a segunda, para os quais o político e o religioso podem relacionar-se e interagir desde que, púlpito e palanque não se misturem e/ou sejam confundidos no que tange as finalidades a que cada um se destina.

Em segundo lugar, que dadas as especificidades históricas que condicionaram tanto a consolidação do campo evangélico como afro-brasileiro há, no caso das três cidades estudadas, algumas recorrências. Destas, um certo conjunto delas se refere ao contato que diferentes pastores e pais-de-santo ensaiaram ao longo dos últimos anos. E o caso, por exemplo, da entrada de Anabella Schiaffino na política a partir do contato que teve com o missionário R. R. Soares, conforme ela relata em entrevista realizada, ou da forma como, tanto a Deus é Amor como quanto a Igreja Universal se colocam na esfera pública seguindo, para além de suas fronteiras nacionais de origem, as diretrizes da matriz brasileira.

Outras, as especificidades históricas e a forma como se deu nestes países a passagem do neopentecostalismo mass-media para o que muitos autores denominam de pós-denominacionalismo. A primeira delas se deve ao fato de que, a revelia do que se observa no Brasil, tanto na Argentina como no

Debates do NER, Porto Alegre, ano io, N. I6, P. I6I-I8I, JUl./Dez. 2009 
Uruguai, a presença deste segmento na mídia televisiva e radiofônica, no contexto de um neopentecostalismo mass-media foi muito menor, apesar de algumas igrejas possuírem, nestes dois países, alguns programas e/ou emissoras de sinal televisivo e radiofônico. A segunda deriva do fato de que, dada a pluralidade de novos ministérios, apostolados, comunidades e denominações de pequeno porte que escapam ao jugo das mega-igrejas, tornou-se difícil que, pelo menos no caso argentino, certa unidade de posicionamento fosse construída e, estes, conseguissem lidar com as próprias tensóes inerentes ao campo e a forma como o segmento evangélico têm crescido nos últimos anos ao largo de sua não-institucionalização no interior de grandes igrejas. A terceira e desta decorrente de que, devido ao fracasso de sua inserção no político (Wynarczyk, 2006), a revelia do que se observa no Brasil, na Argentina os evangélicos deste campo se alijaram e de certa forma, perderam força e unidade, esta, manifesta na pouca representatividade que os conselhos de pastores possuem na cena buenarense.

Já no caso uruguaio, apesar de estes estarem bem menos avançados no que tange a emergência de um campo religioso pós-denominacional, estes, parecem deter certa unidade de posição - todavia, tal unidade se mostra muito mais fundada em redes interpessoais de pastores e pais-de-santo do que em entidades representativas deste segmento. Neste sentido, importa observar, também, a forma como estes diferentes estados nacionais se relacionam com o religioso na medida em que, no Brasil, essa relação se opera em termos de uma certa compatibilização entre diferentes crenças que conseguem interagir de forma mais ou menos tranqüila, ocupando, cada uma, o espaço a ela reservado. Movimento este, semelhante ao que observamos no Uruguai ${ }^{10}$ nos dias 28 e 29 de abril de 2009 , quando, em razão de evento

${ }^{10}$ Contudo, não devemos nos assentar em uma falsa premissa, e sim, ter claro que esse movimento é algo bastante recente e que, dadas as premissas liberais fortemente presentes no laicismo uruguaio, por lá, na República Oriental do Uruguai, todas as religiōes que existem no país estão colocadas em um relativo pé de igualdade para com o Estado, de modo que, não há antecedentes, muito menos um horizonte futuro, que torne possível uma maior intimidade do Estado para com algum grupo religioso em específico, como ocorre tanto no Brasil como na Argentina em relação ao catolicismo.

Debates do NER, Porto Alegre, ano io, N. I6, P. I6I-I8I, JUl./DeZ. 2009 
promovido pela Conselho Latino Americano de Igrejas (CLAI) se reuniram no anexo do Senado ${ }^{11}$, lideranças de quase todos os segmentos religiosos montevideanos ${ }^{12}$ que buscaram, nestes dois dias, sistematizar propostas de redução da intolerância religiosa e fornecer ao estado uruguaio algumas diretrizes e valores que permitam a esses dois atores sociais, interagir e colaborar na construção de uma sociedade mais justa e igualitária para todos ${ }^{13}$. Isto, de certa forma diverso daquilo que se faz presente no caso argentino, onde, apesar de o Estado declarar-se constitucionalmente laico já faz algum tempo, em seu interior, como em tempos outros, o catolicismo continua a ser a religião preferencial ${ }^{14}$.

E, em terceiro lugar, que há, pelo menos no contexto dos países estudados pelo menos duas dinâmicas de expansão que se fazem presente entre o segmento evangélico e afro-brasileiro, a saber: a internacionalização e a transnacionalização, as quais, se vinculam a modelos organizacionais dis-

${ }^{11}$ Tal evento, promovido pela CLAI é o resultado de iniciativa é parte de um conjunto de seis diálogos sociais promovidos pela atual presidência pro-tempore do MERCOSUL de Don Fernando Lugo e seus resultados serão apresentados no dia 4 de julho na Reunião de Presidentes que será realizada em Assunção em razão da passagem da presidência protempore do MERCOSUL de Don Fernando Lugo para o atual presidente do Uruguai, Tabaré Vásquez.

${ }^{12}$ Participaram do evento, segundo noticia o Blog de Nicolas Iglesias Schneider, um dos facilitadores do evento e com o qual tivemos a oportunidade de travar um bom diálogo, representantes da Igreja Católica Apostólica Romana, da Federação de Igrejas Evangélicas do Uruguai, da Comissão de Representatividade Evangélica, dos Anglicanos, do Judaísmo, da Federação de Famílias, dos Muçulmanos, dos Afro-umbandistas, de Fe-Bahai, além de, Budistas, Mórmons, Brama Kumaris e organizaçóes ecumênicas como a JPC, a SEDHU, a OBSUR, entre outras.

${ }^{13}$ Deste encontro resultou um documento que foi entregue ao vice-presidente uruguaio, Rodolfo Nin, no dia 26 de maio de 2009 as 15 h30, em cerimônia realizada no anexo do Palácio Legislativo. No documento, os religiosos ligados as mais diferentes matrizes religiosas apresentam suas preocupaçóes e sugestóes ao governo uruguaio no que tange a relação que o Estado uruguaio mantêm hoje com as mais diversas religiosidades, a cidadania religiosa, as diferenças sociais e ao cuidado com o meio ambiente.

${ }^{14} \mathrm{Na}$ medida em que, esta supremacia do catolicismo quando não garantida em lei, o é, pelos usos e costumes das sucessivas administraçóes estatais, como exposto por Semán (2006, p. 9-10).

Debates do NER, Porto Alegre, ano io, N. I6, P. I6I-I8I, JUl./Dez. 2009 
tintos, um do tipo empresarial (IURD, IIGD, DA, etc.), e outro, do tipo congregacional com até 20.000 membros (BRASA, CF, MANAIM, etc.).

No primeiro modelo, o que prevalece é um estrutura fortemente hierarquizada com pouco espaço para o trabalho pastoral autônomo de modo que, neste modelo, grande parte do poder de decisão e da gestão econômica da "empresa religiosa" já esta dada a priori, a partir do riso dissimulado dos bispos, como diria Bourdieu (1996). E deste modo, nesse caso não estaríamos falando em transnacionalização, mais sim, de uma internacionalização de seu mercado de fiéis e uma adaptação de seu produto a realidade local, uma vez que, há um fluxo unidirecional de informaçôes que muito pouco interage e se deixa influenciar por ruídos externos aquilo que provêm de sua matriz denominacional.

Já no caso do segundo modelo organizacional, o que temos é uma maior prevalência dos interesses da comunidade e uma certa especialização no que tange aos serviços espirituais oferecidos por estas congregaçóes de modo que, é muito comum o trânsito de fiéis entre essas diferentes "religiōes especializadas" com vistas a resolução de problemas específicos. E de fato, tal reconhecimento deste outro, permite que, indivíduos e pessoas de grande prestígio no meio evangélico ${ }^{15}$ transitem no interior destas comunidades através de mega-eventos destinados a esse público e/ou a suas lideranças. Todavia, o que prevalece nesses casos é muito mais as redes interpessoais e contato que suas lideranças possuem com outros ministérios e/ou congregaçóes, além é claro, do desejo que essas lideranças possuem em trocar experiências e renovar no plano imagético-simbólico-ritual vivências e experiências religiosas eficazes, como o fez célebre Quesalid, conforme nos relata Levi-Strauss (1995).

Dito de outra forma, temos então que nos foi possível a partir do exposto elaborar um tipologia ideal que em textos posteriores deverá ser melhor desenvolvida na medida em que articula modelos organizacionais

${ }^{15}$ Como por exemplo, é o caso de Benny Hinn, do Ministério Benny Hinn, que esteve em Porto Alegre em 2008; de Carlos Annacondia, do Ministério Mensagem de Salvação, que esteve em Pelotas também em 2008 e/ou de Claúdio Freidzon, da Igreja Rey de Reyes, que estará em novembro na cidade de Curitiba/PR.

Debates do NER, Porto Alegre, Ano io, N. I6, P. I6I-I8I, JUl./Dez. 2009 
diferenciados e formas de estar no mundo, no secular, diversas, onde: Se por um lado temos aqueles que articulam um modelo empresarial de gestão a forma como se colocam na coisa pública, seja dentro ${ }^{16}$ ou fora dela ${ }^{17}$ e que, tem como modo de expansão a internacionalização de sua fé em função de novos mercados; por outro, temos aqueles que, baseados num modelo de crescimento mais controlado, baseados em estratégias de iglecrescimento, buscam trazer para sua congregação novos referenciais imagético-rituais através de um constante ir e vir de pastores que transitam entre ministérios e/ou congregaçóes, formando uma rede transnacional de pastores que no caso dos evangélicos nela transitam ${ }^{18}$.

\section{REFERÊNCIAS BIBLIOGRÁFICAS}

BEM, Daniel Francisco de. Caminhos do Axé: a transnacionalização religiosa para os países platinos a partir do terreiro de Mãe Chola de Ogum, de Santana do Livramento-RS. Porto Alegre: PPGAS/UFRGS, 2007. Dissertação de Mestrado.

BOURDIEU, Pierre. O Poder simbólico. Rio de Janeiro: Bertrand Brasil, 2007. . Razões práticas: sobre a teoria da ação. Campinas: Papirus, 1996.

LEVI-STRAUSS, Claude. "El hechicero y su magia". IN: . Antropologia Estructural 2. Barcelona: Paidós, 1995, p. 195-210.

MEIRELLES, Mauro. "As coisas fora do lugar: o deslocamento de sentido da ação e a práxis estruturada das religiōes afro-brasileiras do Rio Grande do Sul". IN: Debates do NER (UFRGS), n. 13, Porto Alegre, 2008. pp. 47-60.

. "O ritual de libertação e cura iurdiano segundo a perspectiva de Mikhail Bakhtin". IN: Debates do NER (UFRGS), n. 7, Porto Alegre, 2005. pp. 99107.

\footnotetext{
${ }^{16}$ No caso nos referimos mais precisamente a Igreja Universal do Reino de Deus e a Igreja Internacional da Graça de Deus.

${ }^{17}$ Como é o caso, por exemplo, da Igreja Deus é Amor.

${ }^{18}$ Algo observado, também, entre os afro-brasileiros, como vimos anteriormente no que se refere ao caso Mãe Yeda de Ogum, de Pai Cléon de Oxalá e Jorge Verardi de Xangô.
}

Debates do NER, Porto Alegre, ano io, N. I6, P. I6I-I8I, JUl./Dez. 2009 
ORO, Ari Pedro. Axé MERCOSUL: As religiōes afro-brasileiras nos países do Prata. Porto Alegre: Editora Vozes, 1999.

PIERUCCI, Antônio Flávio. "Secularização em Max Weber: Da contemporânea serventia de voltarmos a acessar aquele velho sentido". IN: Revista Brasileira de Ciências Sociais, n. 37, São Paulo, 1998. pp. 43-73.

RAMA, Angel. Ángel Rama: literatura e cultura na América Latina. São Paulo: Edusp, 2001

SEMÁN, Pablo. Introducão. IN: ORO, Ari Pedro (Org.). Religiáo e Política no Cone Sul: Argentina, Brasil e Uruguai. São Paulo: Attar, 2006. pp. 9-32.

WEBER, Max. A Ética Protestante e o Espírito do Capitalismo. São Paulo: Martin Claret, 2002.

WYNARCZYK, Hilário. "Partidos políticos evangélicos conservadores bíblicos en la Argentina: formación y ocaso 1991-2001”. IN: CIVITAS, v. 6, n. 2, Porto Alegre, 2006. pp. 11-42. 
